Journal of Organometallic Chemistry, 238 (1982) 87-97

Elsevier Sequoia S.A., Lausanne - Printed in The Netherlands

\title{
METAL COMPLEX-CATALYZED REDISTRIBUTION REACTIONS OF ORGANOSILANES
}

\section{IV * REDISTRIBUTION REACTIONS OF METHYLSILOXANES CATALYZED BY TRANSITION METAL COMPLEXES}

WAYNE A. GUSTAVSON, PAUL S. EPSTEIN and M.D. CURTIS *

Department of Chemistry, The University of Michigan, Ann Arbor, MI 48109 (U.S.A.) (Received May 4th, 1982)

\section{Summary}

Redistribution reactions of a variety of hydrogen-substituted siloxanes are catalyzed by various transition metal complexes of iridium and rhodium. The products arise from breaking and remaking of $\mathrm{Si}-\mathrm{C}, \mathrm{Si}-\mathrm{H}$, and $\mathrm{Si}-\mathrm{O}$ bonds. Siloxanes not possessing a $\mathrm{Si}-\mathrm{H}$ bond are inert under the conditions studied. The most favored reaction pathway appears to scramble preferentially the groups directly attached to the silicon bearing the hydrogen atom. A new cyclo-iridiadisiloxane, $\mathrm{L}_{2}(\mathrm{CO})(\mathrm{H}) \operatorname{Ir}(\mathrm{SiMeROSiMeR})\left(\mathrm{L}=\mathrm{Ph}_{3} \mathrm{P} ; \mathrm{R}=\mathrm{Me}_{3} \mathrm{SiO}\right)$ is reported. This compound exists in three isomeric forms as a consequence of the spatial arrangements of the $R$ and Me groups on the ring.

\section{Introduction}

In an investigation of small-ring metallacycles, Curtis and Greene [1] found that cyclo-metalladisiloxanes (1) were catalysts for the disproportionation of tetramethyldisiloxane ( $\left.E^{\prime} E^{\prime}\right)$ [2] into dimethylsilane and oligomeric siloxanes $\left(E^{\prime} D_{n} E^{\prime}\right)$ [2] (eq. 1).

A mechanism was proposed [1b and 1c] in which the strain in the four membered ring assisted the scission of an $\mathrm{Si}-\mathrm{O}$ bond in 1 to give reactive, coordinated silylene and silanone intermediates. The crystal structure of $1 \mathrm{a}$ lent support to the argument that the $\mathrm{Si}-\mathrm{O}$ bond is weakened in the metallacycle [3].

The proposed mechanism dealt specifically with the iridium complex (1a)

* For parts I-III see ref. 1. 


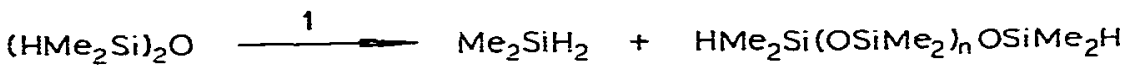

$$
\begin{aligned}
& \text { ( } \left.E^{\prime} E^{\prime}\right) \\
& \left(E^{\prime} D_{r} E^{\prime}\right)
\end{aligned}
$$

\begin{tabular}{|c|c|}
\hline & $L_{n} M$ \\
\hline 0 & $\left(\mathrm{Ph}_{3} \mathrm{P}\right)_{2}(\mathrm{CO})(\mathrm{H}) \mathrm{Ir}$ \\
\hline $1 \mathrm{~b}$ & $\begin{array}{l}\left(\mathrm{Ph}_{3} \mathrm{P}\right)_{2} \mathrm{Pt} \\
\left(\mathrm{Ph}_{3} \mathrm{P}\right)_{2} \mathrm{Pd}\end{array}$ \\
\hline
\end{tabular}<smiles>CN1[Si](C)(C)O[Si]1(C)C</smiles>

(1)

but could be extended to some of the other complexes with minor modifications. Some consequences of the proposed mechanism are that: (i) only those siloxanes possessing the 1,3-dihydrido functionality would undergo facile redistribution since only the $\mathrm{Si}-\mathrm{H}$ bond reacts readily with the low valent metal complexes, and the 1,3-arrangement is necessary to form the fourmembered ring; (ii) only $\mathrm{SiO} / \mathrm{H}$ exchange (see below) should occur, and (iii) the oligomers are formed sequentially, i.e., $2 E^{\prime} E^{\prime} \rightarrow E^{\prime} \mathrm{DE}^{\prime}+\mathrm{Me}_{2} \mathrm{SiH}_{2} ; \mathrm{E}^{\prime} \mathrm{E}^{\prime}+$ $E^{\prime} \mathrm{DE}^{\prime} \rightarrow \mathrm{E}^{\prime} \mathrm{D}_{2} \mathrm{E}^{\prime}+\mathrm{Me}_{2} \mathrm{SiH}_{2} ; \mathrm{E}^{\prime} \mathrm{E}^{\prime}+\mathrm{E}^{\prime} \mathrm{D}_{2} \mathrm{E}^{\prime} \rightarrow \mathrm{E}^{\prime} \mathrm{D}_{3} \mathrm{E}^{\prime}+\mathrm{Me}_{2} \mathrm{SiH}_{2}$, etc.

The general features of the Ir-catalyzed reaction seemed to fit all these requirements, at least at low conversions [1c]. After longer reaction times, various secondary products were observed. In order to characterize further the redistribution reaction and the effects of using different metals and different silanes, the present work was undertaken. The results show that the reaction is much more complex than originally thought and that the originally proposed metallacycle mechanism, if it is operative at all, cannot be the only mechanism whereby the groups on silicon are redistributed.

\section{Experimental}

All manipulations involving solutions of catalysts, reaction mixtures, etc. were done with standard Schlenk techniques under a nitrogen atmosphere. Proton and ${ }^{13} \mathrm{C}\left\{{ }^{1} \mathrm{H}\right\}$ NMR spectra were recorded on a JeoI JNM-PS-100 spectrometer or on a Varian T-60A. Gas chromatograms were obtained on an Antek 300, aual column instrument equipped with a thermal conductivity detector. Recording and integration of the GC spectra were accomplished with a Hewlett Packard 3380A integrator-plotter. The analytical column employed was $14^{\prime} \times 1 / 8^{\prime \prime}$ S.S. packed with $5 \%$ SE-30 on Chromosorb WHP 80/100. The carrier gas was He at a flow rate of $10 \mathrm{ml} / \mathrm{min}$. Typical GC conditions are: Injector, $250^{\circ} \mathrm{C}$; Detector, $300^{\circ} \mathrm{C}$; temperature program: 2 min at $40^{\circ} \mathrm{C}$, then increase at $4^{\circ} / \mathrm{min}$ to $225^{\circ} \mathrm{C}$. The preparative.GC column consisted of $15^{\prime} \times 1 / 4^{\prime \prime}$ S.S. packed with $20 \%$ SE-30 on Chromosorb A 40/60.

Mass spectra were recorded on an AEI MS902 (pure components) or on the Finnegan 4000 quadrupole spectrometer interfaced to a temperature programmable GC column, the whole being controlled by the INCOS data acquisition system [4]. When operating in the GC/MS mode, the spectra were typically 
"enhanced", a procedure whereby the computer substracts out peaks which are judged to be background on the basis of their mass chromatograms. Parent ions were located either by mass chromatography (mass vs. time) or by chemical ionization techniques [4].

In cases where mass spectrometry alone would not resolve the identity of a compound, e.g., between the isomers $E^{\prime} D D E^{\prime}$ and $E D^{\prime} D^{\prime} E$, the substance in question was isolated by preparative GC and analyzed by ${ }^{1} \mathrm{H}$ - and/or ${ }^{13} \mathrm{C}-\mathrm{NMR}$ spectroscopy. Once the identity of a compound was established, its mass spectrum was stored in the computer library. Future occurences of the compound in mixtures could then be established by comparing its mass spectrum with the library spectrum peak for peak.

The following code will be used in the Tables to indicate the manner in which various substances were identified: 1 - comparison of GC retention times and computer matching of the mass spectra to those of authentic samples; 2 - as in method 1 plus the isolation of the product by preparative GC and analysis of its ${ }^{1} \mathrm{H}$ - and/or ${ }^{13} \mathrm{C}-\mathrm{NMR}$ spectra; 3 - analysis based on comparing GC retention times and MS fragmentation patterns with similar substances according to empirical rules developed in the course of this work [5] and by others [6], 4 - as in methods 1 or 3 plus substitution of $\mathrm{Ph}$ by $\mathrm{Ph}-d_{5}$.

Starting siloxanes were purchased from Petrarch and were distilled prior to use. Tetramethyldisiloxane was prepared by hydrolysis of $\mathrm{Me}_{2} \mathrm{SiHCl}$, obtained from Dow Corning Corp. Vaska's and Wilkinson's complexes, $\mathrm{L}_{2}(\mathrm{CO}) \mathrm{ClIr}$ and $\mathrm{L}_{3} \mathrm{Rh} \mathrm{Cl}$, respectively, were prepared by literature methods $[7,8]$. Benzene was dried over potassium/benzophenone and distilled under $\mathrm{N}_{2}$ immediately prior to use.

Synthesis of hydrido-1,3-[trans-bis(1,3-trimethylsiloxy)-1,3-dimethyldisiloxanediyl] carbonylbis(triphenylphosphine)iridium(III), $\mathrm{L}_{2}(\mathrm{CO})(\mathrm{H}) \operatorname{Ir}\left[\mathrm{SiMe}\left(\mathrm{OSiMe}_{3}\right)\right.$ $\left.\left.\mathrm{OSiMe}_{\mathrm{OSiMe}}\right)\right]$ (3)

Vaska's complex, $\mathrm{L}_{2}(\mathrm{CO}) \mathrm{ClIr}(0.6 \mathrm{~g}, 0.8 \mathrm{mmol})$ was slurried in $10 \mathrm{ml}$ of benzene. Then, $0.45 \mathrm{~g}(1.5 \mathrm{mmol})$ of $1,1,1,3,5,7,7,7$-octamethyltetrasiloxane (ED'D'E) was added to give a cloudy, yellow solution which became clear when heated to reflux. After stirring at reflux for $1 \mathrm{~h}$, the solvent was removed under vacuum to give an oil. Trituration with benzene/petroleum ether gave a white solid, m.p. 158-160 ${ }^{\circ} \mathrm{C}$, in $78 \%$ yield based on Ir. The $60 \mathrm{MHz}{ }^{1} \mathrm{H}$ NMR of 2 in the SiMe region consists of two broad peaks at $\delta 0.8$ and 0.6 and a sharper peak at $\delta 0.2 \mathrm{ppm}$. Each of these peaks is obviously composed of overlapping unresolved peaks.

Anal. Found: $\mathrm{C}, 52.04 ; \mathrm{H}, 5.48 ; \mathrm{P}, 6.10 ; \mathrm{Si}, 10.20 ; \mathrm{Ir}, 17.70 . \mathrm{C}_{45} \mathrm{H}_{55} \mathrm{IrP}_{2} \mathrm{O}_{4} \mathrm{Si}_{4}$ calcd.: $\mathrm{C}, 52.65 ; \mathrm{H}, 5.42 ; \mathrm{P}, 6.03 ; \mathrm{Si}, 10.95 ; \mathrm{Ir}, 18.72 \%$. The SiOSi stretch occurs as a very strong band between $1000-1100 \mathrm{~cm}^{-1} . \nu(\operatorname{IrH}) 2080 \mathrm{~s} ; \nu(\mathrm{CO})$ $1967 \mathrm{~s} \mathrm{~cm}^{-1}$.

\section{Redistribution reactions}

The conditions for each run are listed as footnotes in the Tables. A typical procedure is described here. Tetramethyldisiloxane $(7.5 \mathrm{ml}, 42 \mathrm{mmol})$ was added to a benzene solution $(25 \mathrm{ml})$ containing $200 \mathrm{mg}(0.26 \mathrm{mmol})$ of $\left(\mathrm{Ph}_{3} \mathrm{P}\right)_{2}(\mathrm{CO}) \mathrm{ClIr}$ under a $\mathrm{N}_{2}$ atmosphere. The reaction flask was equipped with 
a reflux condenser, $\mathrm{N}_{2}$ inlet, and an oil bubbler (attached at the top of the condenser and connected to the $\mathrm{N}_{2}$ source through a $\mathrm{T}$-joint). During the reaction, a static $\mathrm{N}_{2}$ blanket was maintained in the reaction vessel. The flask was immersed in a constant temperature bath for a given time. The bulk of the solvent was then distilled off and the solvent fraction and pot residue analyzed by GC or GC/MS. This concentration step allowed for better determination of . minor components.

\section{Kinetic runs}

In those cases where the kinetics of the redistribution reactions were determined, the reaction flask was also fitted with a $4 \mathrm{~mm}$ diameter side-arm tipped with a septum for GC sampling during the course of the reaction. In addition, a weighed amount of internal standard (n-heptane or n-octane) was added to the stock solutions of catalyst.

\section{Results and discussion}

Tables 1-4 list some of the products observed when various siloxanes containing an $\mathrm{Si}-\mathrm{H}$ bond are treated with transition metal complexes. In addition to the complexes listed, several others, e.g., $\mathrm{Rh}_{2}(\mathrm{CO})_{4} \mathrm{Cl}_{2}, \mathrm{Rh}_{2}\left(\mathrm{C}_{2} \mathrm{H}_{4}\right)_{4} \mathrm{Cl}_{2}$, $\left(\mathrm{C}_{2} \mathrm{H}_{4}\right)_{2} \mathrm{Rh}(\mathrm{acac})$, and $\mathrm{L}_{2} \mathrm{Pt}\left(\mathrm{SiMe}_{2} \mathrm{OSiMe}_{2}\right)\left(\mathrm{L}=\mathrm{Ph}_{3} \mathrm{P}\right.$ unless explicitly stated otherwise), also were found to catalyze the redistribution of tetramethyl-

TABLE 1

REDISTRIBUTION PRODUCTS OF TETRAMETHYLDISILOXANE (E'E') CATALYZED BY $\mathrm{L}_{2}(\mathrm{CO}) \mathrm{CII}$ AND $\mathrm{L}_{3} \mathrm{RhCl}$

\begin{tabular}{|c|c|c|c|c|c|}
\hline Product & $90 \operatorname{Ix}^{a}$ & $90 \mathrm{Rh}^{b}$ & Anal. & $\begin{array}{l}\text { Exchange } \\
\text { type }\end{array}$ & Substrate \\
\hline $\operatorname{Si}_{1} \mathrm{PhSimle}_{2} \mathrm{H}$ & 1.1 & - & 1 & $\mathrm{Ph} / \mathrm{H}^{e}$ & $\mathrm{Me}_{2} \mathrm{SiH}_{2}$ \\
\hline $\sin _{2} E^{D_{E^{\prime}}}$ & 1.0 & 2.0 & 1 & $\mathrm{Ph} / \mathrm{H} e$ & $E^{\prime} E^{\prime}$ \\
\hline $\begin{array}{c}\operatorname{Si}_{3} E^{\prime} \mathbf{D E ^ { \prime }} \\
\mathbf{E}^{\prime} \mathbf{D}^{\prime} \mathbf{E}^{\prime} \\
\mathbf{D}_{\mathbf{3}} \\
\mathbf{D}_{\mathbf{2}} \mathbf{D}^{\prime}\end{array}$ & $\begin{array}{c}60.4 \\
- \\
0.5 \\
0.4\end{array}$ & $\begin{array}{l}8.7 \\
5 \\
0.8 \\
0.8\end{array}$ & $\begin{array}{l}3 \\
1 \\
1 \\
3\end{array}$ & $\begin{array}{l}\mathrm{SiO} / \mathrm{H} \\
\mathrm{SiO} / \mathrm{Me} \\
\mathrm{SiO} / \mathrm{H} f \\
\mathrm{SiO} / \mathrm{Me} f\end{array}$ & $\begin{array}{l}\mathbf{E}^{\prime} \mathbf{E}^{\prime} \\
\mathbf{E}^{\prime} \mathbf{E}^{\prime} \\
\mathbf{E}^{\prime} \mathbf{D}_{\mathbf{2}} \mathbf{E}^{\prime} \\
\mathbf{E}^{\prime} \mathbf{D}_{\mathbf{2}} \mathbf{E}^{\prime}\end{array}$ \\
\hline $\begin{array}{l}S_{4} E^{\prime} D_{2} E^{\prime} \\
E^{\prime} \mathbf{D}^{\prime} E^{\prime} \\
E^{\prime} \mathbf{D}_{2}^{\prime} E^{\prime} \\
\mathbf{D}_{4} \\
\mathbf{D}_{3} \mathbf{D}^{\prime}\end{array}$ & $\begin{array}{l}21 \\
1.4 \\
\text { trace } \\
1.1\end{array}$ & $\begin{array}{c}13 \\
13 \\
1.3 \\
4.1 \\
-\end{array}$ & $\begin{array}{l}\mathbf{2} \\
\mathbf{3} \\
\mathbf{3} \\
\mathbf{1} \\
\mathbf{3}\end{array}$ & $\begin{array}{l}\mathrm{SiO} / \mathrm{H} \\
\mathrm{SiO} / \mathrm{Me} \\
\mathrm{SiO} / \mathrm{Me} \\
\mathrm{SiO} / \mathrm{H} f \\
\mathrm{SiO} / \mathrm{Me}^{f}\end{array}$ & $\begin{array}{l}\mathbf{E}^{\prime} \mathbf{D} \mathbf{E}^{\prime} \\
\mathbf{E}^{\prime} \mathbf{D} \mathbf{E}^{\prime} \\
\mathbf{E}^{\prime} \mathbf{D}^{\prime} \mathbf{E}^{\prime} \\
\mathbf{E}^{\prime} \mathbf{D}_{\mathbf{3}} \mathbf{E}^{\prime} \\
\mathbf{E}^{\prime} \mathbf{D}_{\mathbf{3}} \mathbf{E}^{\prime}\end{array}$ \\
\hline $\begin{array}{l}S_{i 5} E^{\prime} D_{3} E^{\prime} \\
E^{\prime} D_{2} D^{\prime} E^{\prime} \\
E^{\prime} D D^{\prime} D E^{\prime}\end{array}$ & $\begin{array}{l}2.0 \\
6.0 \\
0.2\end{array}$ & $\begin{array}{r}8.6 \\
10.3 \\
4.0\end{array}$ & $\begin{array}{l}\mathbf{1} \\
\mathbf{3} \\
\mathbf{3}\end{array}$ & $\begin{array}{l}\mathrm{SiO} / \mathrm{H} \\
\mathrm{SiO} / \mathrm{Me} \\
\mathrm{SiO} / \mathrm{H}\end{array}$ & $\begin{array}{l}\mathbf{E}^{\prime} \mathbf{D}_{\mathbf{2}} \mathbf{E}^{\prime} \\
\mathbf{E}^{\prime} \mathbf{D}_{\mathbf{2}} \mathbf{E}^{\prime} \\
\mathbf{E} \mathbf{D} \mathbf{D}^{\prime} \mathbf{E}^{\prime}\end{array}$ \\
\hline$S^{i_{6}} E^{\prime} D_{4} E^{\prime}$ & 2.0 & 11.3 & 1 & $\mathrm{SiO} / \mathrm{H}$ & $E^{\prime} D_{3} E^{\prime}$ \\
\hline
\end{tabular}

$a_{4 \mathrm{ml} \mathrm{E}}^{\prime} \mathrm{E}^{\prime}, 2 \mathrm{ml} \mathrm{PhH}, 120 \mathrm{mg} \mathrm{L}$ (CO)ClIr (140/1, $\mathrm{E}^{*} \mathrm{E}^{\prime} / \mathrm{L}_{2}$ (CO)CHr), $60^{\circ} \mathrm{C}_{2} 48 \mathrm{~h} ; 39 \%$ conversion. ${ }^{b} 6 \mathrm{ml}$ $E^{\prime} E^{\prime}, 4 \mathrm{ml} \mathrm{PhH,} 120 \mathrm{mg} \mathrm{L} \mathrm{RhCl}\left(260 / 1, \mathrm{E}^{\prime} \mathrm{E}^{\prime} / \mathrm{Rh}\right)$ catalyst, $60^{\circ} \mathrm{C}, 17 \mathrm{~h} ; 14 \%$ conversion. ${ }^{2}$ Analysis code see Experimental section. ${ }^{\prime} \mathrm{SiO} / \mathrm{H}$ refers to the reaction: $\mathrm{Si}(M e) H+\mathrm{E}^{\prime} \mathrm{E}^{\prime} \rightarrow \mathrm{Si}^{\prime}(\mathrm{Me}) \mathrm{OSiMe}_{2} \mathrm{H}+\mathrm{Me}_{2} \mathrm{SiH}_{2}$ : SiO/Me refers to: $\mathrm{Si}(M e)(H)+\mathrm{E}^{\prime} \mathrm{E}^{\prime} \rightarrow \mathrm{Si}\left(\mathrm{H}^{\prime} \mathrm{OSiMe}_{2} \mathrm{H}+\mathrm{Me}_{3} \mathrm{SiH}\right.$. (Si(Me)H groups are considered to be the substrates). ${ }^{e}$ Exchange with benzene solvent (see text). ${ }^{f}$ Internal exchange (see text). 
disiloxane ( $\left.E^{\prime} E^{\prime}\right)$. However, the products are essentially the same as those listed in Table 1.

Siloxanes which do not have at least one $\mathrm{Si}-\mathrm{H}$ bond are inert under the conditions described in Tables 1-4. Thus, $D_{3}, D_{4}, E E$, and EDE remain unchanged in the presence of the transition metal complexes which cause redistribution of hydrido-siloxanes. These permethylsiloxanes are also inert in the presence of a hydrido silane and the transition metal complex. This latter observation rules out the possibility that the observed reactions occur as a result of catalysis by acidic metal "hydrides" formed in the reaction mixture.

As Table 1 shows, all the redistribution products of $E^{\prime} E^{\prime}$ may be rationalized as arising from exchanges of groups adjacent to the $\mathrm{Si}-\mathrm{H}$ functionality (e.g., eq. 2,$3 ; R^{\prime}=\mathrm{HMeSiO}$ ).

$$
\mathrm{R}^{\prime} \mathrm{Me}_{2} \mathrm{SiH}+R^{\prime} \mathrm{Me}_{2} \mathrm{SiH} \underset{\text { exchange }}{\frac{\mathrm{SiO} / \mathrm{H}}{\mathrm{R}^{\prime} \mathrm{Me}_{2} \mathrm{SiR}^{\prime}}} \underset{\left(\mathrm{E}^{\prime} \mathrm{DE} \mathrm{E}^{\prime}\right)}{ }+\mathrm{Me}_{2} \mathrm{SiH}_{2}
$$

$$
\mathrm{R}^{\prime} \mathrm{Me}(\mathrm{H}) \mathrm{SiMe}+\mathrm{R}^{\prime} \mathrm{Me} \mathrm{S}_{2} \mathrm{SiH} \underset{\text { exchange }}{\mathrm{SiO} M \mathrm{Me}} \mathrm{R}^{\prime} \mathrm{Me}(\mathrm{H}) \mathrm{SiR}^{\prime}+\mathrm{Me}_{3} \mathrm{SiH}
$$

A second $\mathrm{SiO} / \mathrm{H}$ exchange on $\mathrm{E}^{\prime} \mathrm{DE}^{\prime}$ with $\mathrm{E}^{\prime} \mathrm{E}^{\prime}$ (present in excess) gives the next higher oligomer according to eq. $4\left(R^{\prime \prime}=\mathrm{HMe}_{2} \mathrm{SiOSi}(\mathrm{Me})_{2} \mathrm{O}\right)$. Continuing

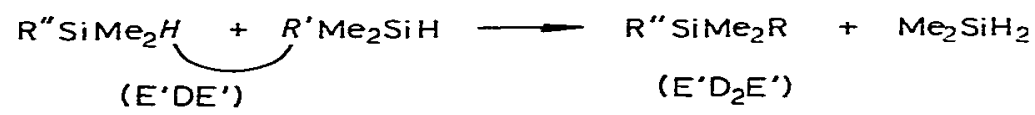

in this manner, the oligomers $\mathrm{E}^{\prime} \mathrm{D}_{n} \mathrm{E}^{\prime}$ are formed sequentially via $\mathrm{SiO} / \mathrm{H}$ exchange. This is by far the most favored reaction pathway for the iridium catalysis of $E^{\prime} E^{\prime}$ redistribution, and is the reaction pathway in accord with the metallacycle mechanism previously proposed $[1 \mathrm{~b}, 1 \mathrm{c}]$.

However, the minor products appear to arise from SiO/Me exchange as shown in eq. 3. Other minor products, e.g., the cyclic oligomers $D_{3}$ and $D_{4}$, can be accounted for on the basis of an internal $\mathrm{SiO} / \mathrm{H}$ exchange as shown in eq. 5 (i.e., $E^{\prime} \mathrm{D}_{n-1} \mathbf{E}^{\prime} \rightarrow \mathrm{Me}_{2} \mathrm{SiH}_{2}+\mathrm{D}_{n}$ ).

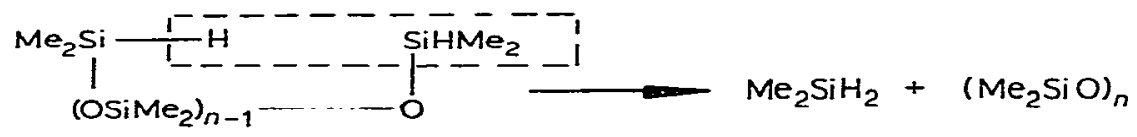

Neither SiO/Me exchange nor the internal $\mathrm{SiO} / \mathrm{H}$ exchange of eq. 5 can be accommodated easily by the metallacycle mechanism. Although there could be two or more mechanisms operative, a faster one involving metallacycles which give the main products and slower ones accounting for the various minor products, it seems more likely that the metallacycles are not directly involved in the catalytic cycle.

With the Ir-catalyzed reactions shown in Table $1, \mathrm{SiO} / \mathrm{H}$ exchange accounts for $86 \%$ of the products shown. Only $50 \%$ of the products from the $\mathrm{Rh}$ - 


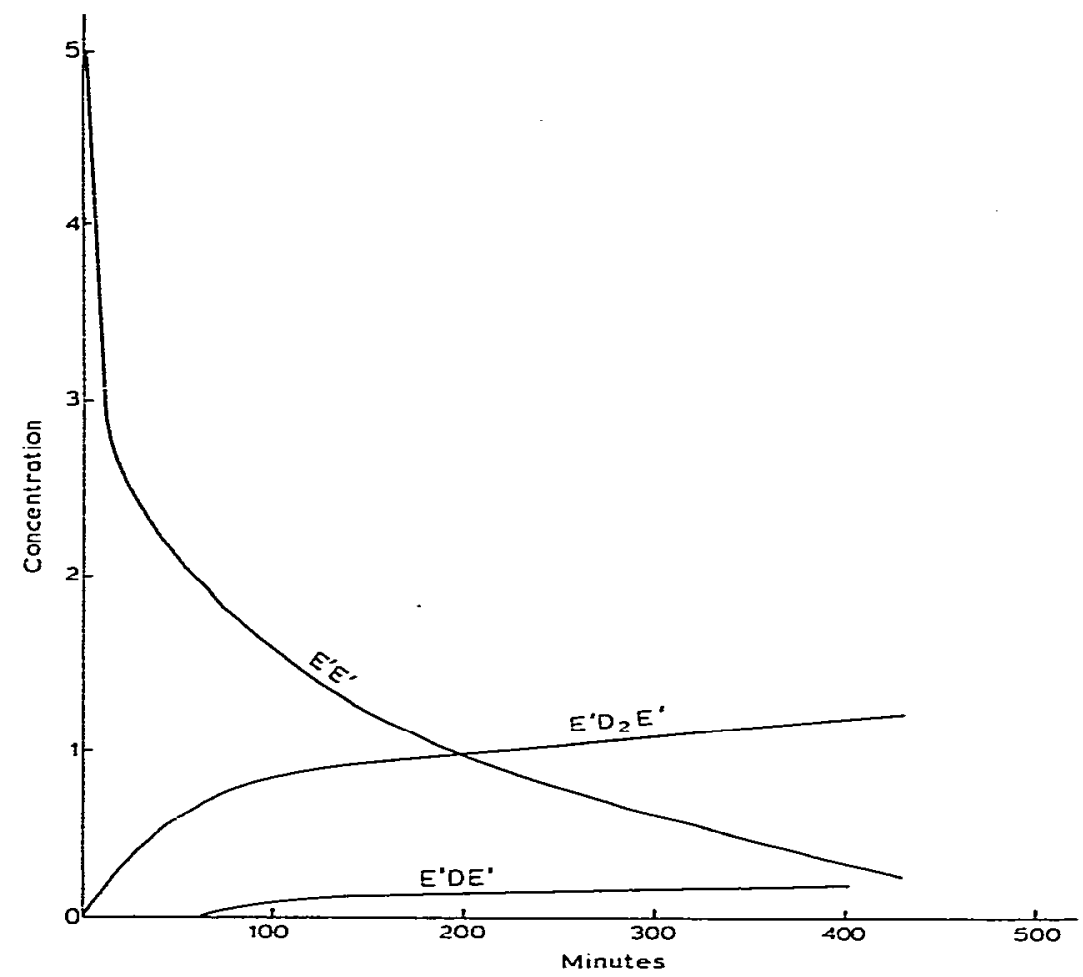

Fig. 1. Concentrations $\left(M \times 10^{3}\right)$ of $E^{\prime} E^{\prime}, E^{\prime} D E^{\prime}$ and $E^{\prime} D_{2} E^{\prime}$ vs. time, catalyzed by $2 \times 10^{-3} M \mathrm{~L}_{3} \mathrm{RhCl}$ at $41^{\circ} \mathrm{C}$.

catalyzed reaction (Table 1 ) can be attributed to $\mathrm{SiO} / \mathrm{H}$ exchange. The $\mathrm{Rh}$ catalyzed reaction also does not give the product distribution predicted on the basis of sequential oligomer formation, $\mathrm{E}^{\prime} \mathrm{DE}^{\prime} \rightarrow \mathrm{E}^{\prime} \mathrm{D}_{2} \mathrm{E}^{\prime} \rightarrow \mathrm{E}^{\prime} \mathrm{D}_{3} \mathrm{E}^{\prime}$, etc. As Figure 1 shows, the oligomer $\mathrm{E}^{\prime} \mathrm{D}_{2} \mathrm{E}^{\prime}$ is in greater concentration than $\mathrm{E}^{\prime} \mathrm{DE} \mathrm{E}^{\prime}$ at all times.

The metallacycle mechanism predicts the initial concentration of $\mathrm{E}^{\prime} \mathrm{DE}^{\prime}$ to be higher than that of $E^{\prime} D_{2} E^{\prime}$ since $E^{\prime} D E^{\prime}$ is the initial, " 1 st turnover" product. Hence, some other mechanism must be operative, even for $\mathrm{SiO} / \mathrm{H}$ exchange, with the rhodium-based catalysts. (Note: oxygen balance requires three mol of $E^{\prime} E^{\prime}$ to produce one of $E^{\prime} D_{2} E^{\prime}$ no matter what the mechanism.)

The siloxanes, pentamethyldisiloxane (EE') and hexamethyltrisiloxane ( $\left.\mathrm{E}^{\prime} \mathrm{DE}^{\prime}\right)$, were subjected to redistribution conditions with $\mathrm{L}_{2}(\mathrm{CO}) \mathrm{ClIr}$ as catalyst. $\mathrm{EE}^{\prime}$ does not have the second hydrogen necessary to form a fourmembered metallacycle and $E^{\prime} D E^{\prime}$ has been shown to give the six-membered metallacycle, 2 [1c].

$L_{2}(C O) C I I r+E^{\prime} D E^{\prime}-$<smiles>[3H][I-]([3H])(O)[Si]1(C)O[Si](C)(C)O[Si](C)(C)O1</smiles> 
These siloxanes undergo redistribution, although at a rate slower than that for $E^{\prime} E^{\prime}$. Figure 2 shows a graph of concentration vs. time for the redistribution of $E E^{\prime}$ and $E^{\prime} E^{\prime}$. These curves are typical for all the redistribution reactions studied to date. There is an initial rapid drop in siloxane concentration, then an abrupt break followed by a slow, zero-order reaction. The zero-order rate constants from the data in Fig. 2 are $6 \times 10^{-5}$ and $85 \times 10^{-5} \mathrm{mmol} / \mathrm{ml} / \mathrm{min}$ for $\mathrm{EE}^{\prime}$ and $\mathrm{E}^{\prime} \mathrm{E}^{\prime}$, respectively. Dividing by the concentration of catalyst gives the turnover numbers, $1.1 \times 10^{-3}$ and $1.6 \times 10^{-2} \mathrm{~mol}$ siloxane/mol catalyst/min, for $\mathrm{EE}^{\prime}$ and $\mathrm{E}^{\prime} \mathrm{E}^{\prime}$, respectively. The rate for $\mathrm{E}^{\prime} \mathrm{E}^{\prime}$ is thus about 16 times that for $\mathrm{EE}^{\prime}$. Whether or not the relatively modest rate increase for $F^{\prime} F^{\prime}$ is due to the operation of the special, metallacyclic mechanism is questionable.

It was also observed that the following catalyst precursors all gave the same turnover numbers after the initial abrupt drop: $\mathrm{L}_{3} \mathrm{RhCl}$ ( $\left.\mathrm{acac}\right) \mathrm{Rh}$ (ethylene) ${ }_{2}$ and $\mathrm{Rh}_{2}(\mathrm{CO})_{4} \mathrm{Cl}_{2}$. This suggests that the final cataly tic species are identical.

The redistribution products of pentamethyldisiloxane ( $\mathrm{EE}^{\prime}$ ) are shown in Table 2. The major product is $\mathrm{ED}^{\prime} \mathrm{E}$ which most likely comes from an exchange of trimethylsiloxy for methyl on $\mathrm{EE}^{\prime}$ (eq. 7). The unsymmetric nature of EE'

$2 \mathrm{Me}_{2} \mathrm{SiOSiMe}_{2} \mathrm{H} \rightarrow \mathrm{Me}_{3} \mathrm{SiOSiMe}(\mathrm{H}) \mathrm{OSiMe}_{3}+\mathrm{Me}_{3} \mathrm{SiH}$

(EE')

(ED'E)

also reveals that $\mathrm{SiO} / \mathrm{SiO}$ exchanges must occur, e.g., eq. 8. The $\mathrm{E}^{\prime} \mathrm{E}^{\prime}$ then redis-

$2 \mathrm{Me}_{3} \mathrm{SiOSiMe}_{2} \mathrm{H} \rightarrow\left(\mathrm{Me}_{3} \mathrm{Si}\right)_{2} \mathrm{O}+\left(\mathrm{HMe}_{2} \mathrm{Si}\right)_{2} \mathrm{O}$

$\left(\mathrm{EE} \mathbf{E}^{\prime}\right)$

(EE)

$\left(E^{\prime} E^{\prime}\right)$

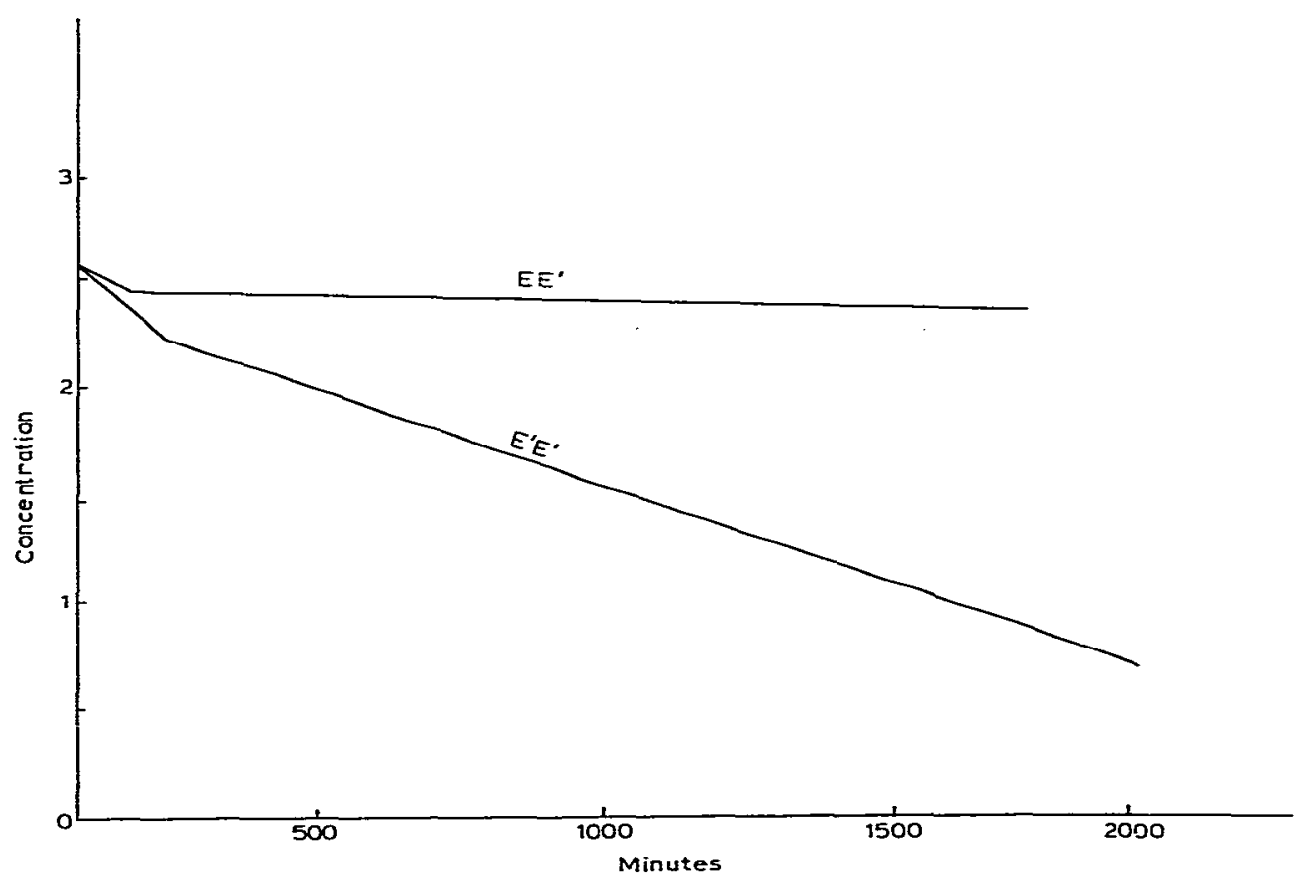

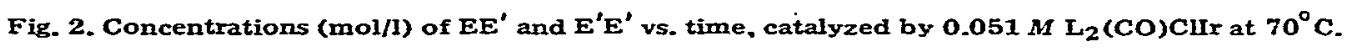


TABLE 2

REDISTRIBUTION PRODUCTS OF PENTAMETHYLDISILOXANE (EE') ${ }^{a}$

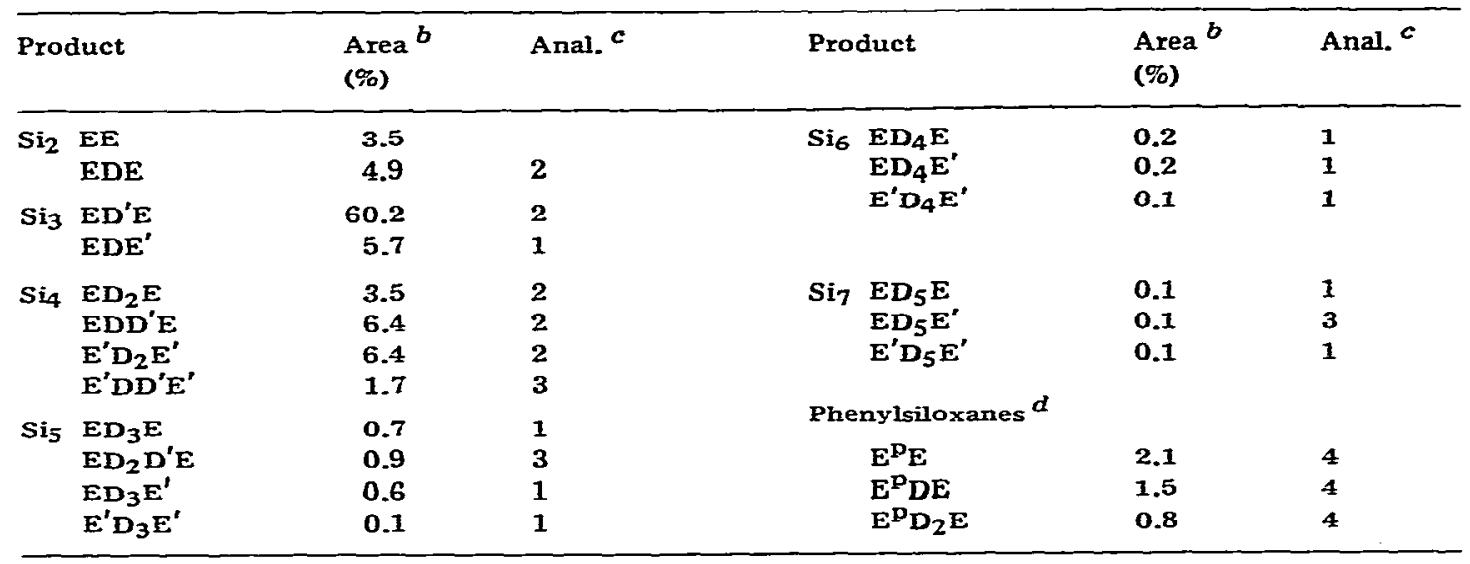

a 39 mmol EE' and $0.773 \mathrm{mmol} \mathrm{L}_{2}(\mathrm{CO}) \mathrm{ClIr}$ in $15.0 \mathrm{ml} \mathrm{C}_{6} \mathrm{H}_{6}$ for $116 \mathrm{~h}$ at $70^{\circ} \mathrm{C} ; 16 \%$ conversion, ${ }^{b} \mathrm{GC}$ area percents of products with $\geqslant 2$ silicon per molecule. Some Mes SiH and EE also detected. ${ }^{C}$ Analysis code, (see Experimental section). $d$ Phenyl groups from solvent, (see text).

tributes further according to eq. $1-5$, etc. In fact, all of the "symmetric" oligomers, $E^{\prime} D_{n} E^{\prime}$ in Table 2 most probably result from SiO/SiO exchanges.

Table 3 presents the redistribution products of $\mathrm{E}^{\prime} \mathrm{DE}^{\prime}$. One of the major products, $\mathrm{E}^{\prime} \mathrm{D}_{2} \mathrm{E}^{\prime}$, is again most probably formed as a result of the SiO/SiO exchange shown in the Table. The other major product is the cyclic tetramer, $D_{3} D^{\prime}$. If this cyclic forms from an internal exchange (cf. eq. 5), then its precursor is $E^{\prime} \mathrm{DD}^{\prime} \mathrm{DE}$, the expected first turnover product resulting from the $\mathrm{SiO} / \mathrm{Me}$ exchange shown in Table 3 . If this scheme is correct, then the $E^{\prime} D^{\prime} D^{\prime} E^{\prime}$ must cyclize nearly as fast as it is formed since its concentration is extremely low for a 1st turnover product.

$E D^{\prime} D^{\prime} E$ reacts with $\mathrm{L}_{2}(\mathrm{CO}) \mathrm{CII}$ to give a mixture of the metallacycles $\mathbf{3 a}-\mathbf{3 c}$ $\left(\mathrm{R}=\mathrm{Me}_{3} \mathrm{SiO}\right)$ [9]. The overall composition is well established by elemental

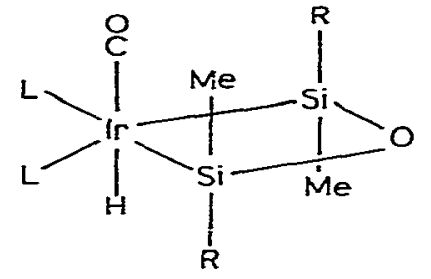

(3a)<smiles>[R]C1([Si]([3H])([3H])[3H])O[Si]1([R])[Si]([3H])([3H])C</smiles>

(3b)

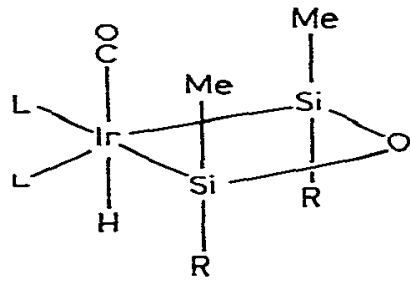

(3c)

analysis. However, the ${ }^{1} \mathrm{H}$ NMR in the Si-Me region consists of a set of overlapping peaks in three main "bunches" at $\delta 0.8,0.6$ and 0.2 . Five peaks and two shoulders are distinguishable. The mixture of isomers $3-5$ should give a total of eight methyl environments.

If the redistribution reaction of $E^{\prime} D^{\prime} E$ were to proceed via the previously proposed metallacycle mechanism, then the primary reaction products would 
TABLE 3

REDISTRIBUTION PRODUCTS OF HEXAMETHYLTRISILOXANE (E'DE')

\begin{tabular}{lcl}
\hline Product $^{a}$ & Area $(\%) b$ & Formation \\
\hline Mes ${ }^{b}$ & 0.1 & - \\
$E^{\prime} D^{\prime} E$ & 0.8 & $E^{\prime} /$ Me on $E^{\prime} D E^{\prime}$ \\
$D_{3} D^{\prime}$ & 48.3 & Cyclization of $E^{\prime} D D^{\prime} D E^{\prime}(?)$ \\
$E^{\prime} D_{2} E^{\prime}$ & 38.1 & $E^{\prime} D / E^{\prime}$ on $E^{\prime} E^{\prime}$ \\
$E^{\prime} D^{\prime} D E^{\prime} d$ & 1.0 & $E^{\prime} D / M E^{\prime}$ on $E^{\prime} D E^{\prime}$ \\
$E^{\prime} D_{3} E^{\prime}$ & 6.1 & $E^{\prime} D / H$ on $E^{\prime} D E^{\prime}$ \\
$E^{\prime} D_{4} E^{\prime}$ & 5.3 & $E^{\prime} D / H$ on $E^{\prime} D_{2} E^{\prime}$ \\
\hline
\end{tabular}

$a_{2} .04 M \mathrm{E}^{\prime} \mathrm{DE} \mathrm{E}^{\prime}$ in benzene; $0.01 \mathrm{M \textrm {L } _ { 2 }}$ (CO)CUr, $60^{\circ} \mathrm{C} ; 46 \mathrm{~h} ; 6 \%$ conversion. ${ }^{b} \mathrm{GC}$ area percents of products only. $c$ Probable mode of formation. ${ }^{2}$ Structure assigned on basis of expected exchange mode.

be given by eq. $9\left(\mathrm{R}=\mathrm{Me}_{3} \mathrm{SiO}\right)$. The oligomeric siloxanes should have pendant

$$
(n+1) \mathrm{ED}^{\prime} \mathrm{D}^{\prime} \mathrm{E} \rightarrow \mathrm{ED}^{\prime}(-\mathrm{T}-)_{n} \mathrm{D}^{\prime} \mathrm{E}+n \mathrm{RMeSiH}_{2}
$$

$\mathrm{Me}_{3} \mathrm{SiO}$ groups along the polymer backbone. The $\mathrm{RMeSiH}_{2}$ should disproportionate very rapidly to give products, e.g., $\mathrm{MeSiH}_{3(g)}$ and $\mathrm{ED}^{\prime} \mathrm{E}$ via $\mathrm{R} / \mathrm{H}(\mathrm{R}=$ $\mathrm{Me}_{3} \mathrm{SiO}$ ) exchanges [9]. However, the products listed in Table 4 are best rationalized by assuming that both SiO bonds adjacent to the hydrogen-bearing silicon are labilized, not just the central $\mathrm{Si}-\mathrm{O}$ bond as would be the case if a metallacycle were necessary to cause labilization.

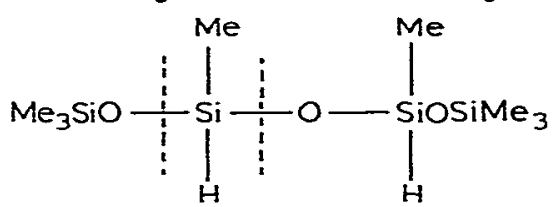

TABLE 4

REDISTRIBUTION PRODUCTS OF OCTAMETHYLTETRASILOXANE (ED'D'E)

\begin{tabular}{|c|c|c|}
\hline Product $a, b$ & Area $\left(\varphi_{0}\right)^{c}$ & Empirical formula \\
\hline 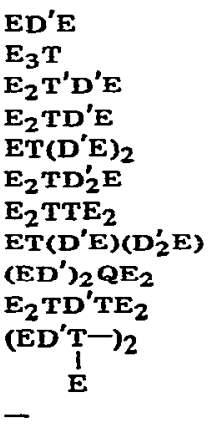 & \begin{tabular}{r|}
13.9 \\
3.4 \\
1.9 \\
7.5 \\
5.0 \\
1.0 \\
1.0 \\
3.3 \\
1.5 \\
3.9 \\
13.1 \\
\\
3.9
\end{tabular} & $\begin{array}{l}\mathrm{Me}_{7} \mathrm{Si}_{3} \mathrm{HO}_{2} \\
\mathrm{Me}_{10} \mathrm{Si}_{4} \mathrm{O}_{3} \\
\mathrm{Me}_{10} \mathrm{Si}_{5} \mathrm{H}_{2} \mathrm{O}_{4} \\
\mathrm{Me}_{11} \mathrm{Si}_{5} \mathrm{HO}_{4} \\
\mathrm{Me}_{12} \mathrm{Si}_{6} \mathrm{H}_{2} \mathrm{O}_{5} \\
\mathrm{Me}_{12} \mathrm{Si}_{6} \mathrm{II}_{2} \mathrm{O}_{5} \\
\mathrm{Me}_{14} \mathrm{Si}_{6} \mathrm{O}_{5} \\
\mathrm{Me}_{13} \mathrm{Si}_{7} \mathrm{H}_{3} \mathrm{O}_{6} \\
\mathrm{Me}_{14} \mathrm{Si}_{7} \mathrm{H}_{2} \mathrm{O}_{6} \\
\mathrm{Me}_{15} \mathrm{Si}_{7} \mathrm{HO}_{6} \\
\mathrm{Me}_{16} \mathrm{Si}_{8} \mathrm{H}_{2} \mathrm{O}_{7} \\
\mathrm{Me}_{17} \mathrm{Si}_{9} \mathrm{H}_{3} \mathrm{O}_{8}\end{array}$ \\
\hline
\end{tabular}

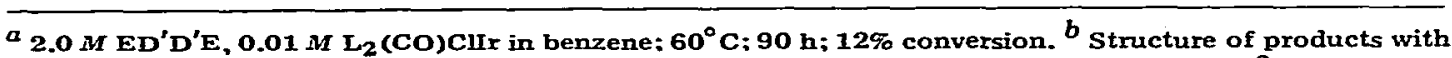
more than $4 \mathrm{Si}$ atoms assigned only on basis of assumed mechanism of formation (see text). $c^{\mathrm{GC}}$ area (\%) of products only. Minor products $(<1 \%)$ omitted. 
In other words, $\mathrm{ED}_{2}^{\prime} \mathrm{E}$, upon its interaction with the catalyst, supplies $\mathrm{E}, \mathrm{ED}_{2}^{\prime}$, and $\mathrm{ED}^{\prime}$ groups for exchange with $\mathrm{Si}-\mathrm{O}, \mathrm{Si}-\mathrm{Me}$, and $\mathrm{Si}-\mathrm{H}$ bonds. The predicted "1st turnover" products are then given by the following equations:

$\mathrm{SiO} / \mathrm{SiO}$ exchanges:

$E D_{2}^{\prime} E \rightarrow\left[E, D_{2}^{\prime} E, E D^{\prime}\right] \rightarrow E D^{\prime} E+E D_{3}^{\prime} E+E D_{4}^{\prime} E$

$\mathrm{SiO} / \mathrm{H}$ exchanges:

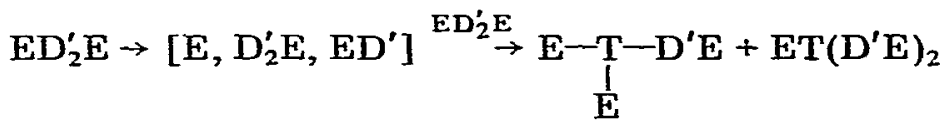

$$
\begin{aligned}
& \left(\mathrm{Si}_{5} \mathrm{H}\right) \quad\left(\mathrm{Si}_{6} \mathrm{H}_{2}\right) \\
& \text {... } E-\underset{\mathrm{D}}{\mathrm{T}}-\mathrm{D}_{2}^{\prime} \mathrm{E} \\
& \left(\mathrm{Si}_{7} \mathrm{H}_{3}\right)
\end{aligned}
$$

$\mathrm{SiO} / \mathrm{Me}$ exchanges:

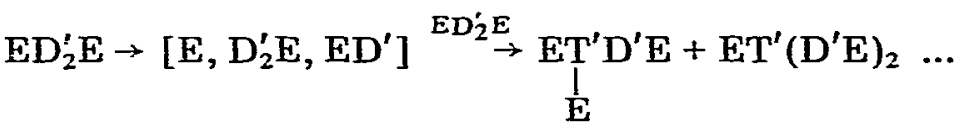

$$
\begin{aligned}
& \left(\mathrm{Si}_{5} \mathrm{H}_{2}\right) \quad\left(\mathrm{Si}_{6} \mathrm{H}_{3}\right) \\
& \begin{array}{l}
+\mathrm{ET}^{\prime} \mathrm{D}^{\prime} \mathrm{E} \\
\quad \mathrm{D}_{2}^{\prime} \mathrm{E} \quad\left(\mathrm{Si}_{7} \mathrm{H}_{4}\right)
\end{array}
\end{aligned}
$$

Of the predicted possibilities, $E D^{\prime} \mathrm{E}$ is definitely observed; and $\mathrm{Si}_{5} \mathrm{H}, \mathrm{Si}_{5} \mathrm{H}_{2}$, two $\mathrm{Si}_{6} \mathrm{H}_{2}$ isomers, and an $\mathrm{Si}_{7} \mathrm{H}_{3}$ isomer are observed. These may possibly correspond to the species in eq. 10-12. The remaining species can all be rationalized as "2nd turnover" products resulting from $\mathrm{E} / \mathrm{H}, \mathrm{ED}^{\prime} / \mathrm{H}, \mathrm{ED}_{2}^{\prime} / \mathrm{H}$, etc. exchanges on the "1st turnover" products. It is interesting to note that the $\mathrm{Si}_{8} \mathrm{H}_{2}$ isomer of possible structure, $\mathrm{ED}^{\prime}[\mathrm{T}(\mathrm{E})]_{2} \mathrm{D}^{\prime} \mathrm{E}$, is a " 2 nd turnover" product according to this scheme, but has the second highest concentration of any product. This same phenomenon occurs in the Rh-catalyzed redistribution of $E^{\prime} E^{\prime}$ wherein the "2nd turnover" product, $E^{\prime} D_{2} E^{\prime}$ has a higher concentration than the supposed "Ist turnover" product, $\mathrm{E}^{\prime} \mathrm{DE}$ ' (see Fig. 1). In any event, the metal complex catalyzed redistribution of $\mathrm{ED}_{2}^{\prime} \mathrm{E}$ leads to a very complex mixture, the composition of which is consistent with the notion that $\mathrm{Si}-\mathrm{O}$ and $\mathrm{Si}-\mathrm{Me}$ bonds adjacent to $\mathrm{Si}-\mathrm{H}$ bonds are labilized and undergo exchange reactions.

Finally, we note that the metal species which are formed in the presence of $\mathrm{Si}-\mathrm{H}$ bonds are sufficiently active to activate the $\mathrm{C}-\mathrm{H}$ bond of benzene to substitution by Si [1a]. As shown in Tables 1 and 2, various phenyl substituted siloxanes and silanes are produced along with the rearrangement products. That the benzene solvent is the source of these phenyl groups in the case of iridium catalysts was demonstrated by using $C_{6} D_{6}$ as the solvent. The resulting phenylcontaining products are $d_{5}$-substituted and their fragmentation patterns are entirely consistent with their being $d_{5}$-phenyl groups [5]. 


\section{Conclusion}

Siloxanes having at least one $\mathrm{Si}-\mathrm{H}$ bond undergo redistribution reactions in the presence of certain transition metal complexes, especially those of $\mathrm{Pt}, \mathrm{Pd}$, Ir and Rh. The observed products are formed as a result of scrambling all the groups attached to the silicon bearing the hydrogen atom; and, to a much lesser extent, as a result of more common $\mathrm{SiO} / \mathrm{SiO}$ exchanges as observed with acid or base catalyzed rearrangements [1b,10]. It appears that with the transition metal catalysts, $\mathrm{SiO} / \mathrm{Me}$ and $\mathrm{SiO} / \mathrm{H}$ exchanges are faster than $\mathrm{SiO} / \mathrm{SiO}$ exchanges, so that these redistributions complement the classical acid or base catalyzed redistributions. Synthetically useful rates and selectivities have been achieved recently by supporting the iridium complexes on high surface area oxides [11].

The nature of the metal-silyl species involved in the catalytic cycle is unclear, although several possibilities have been discussed in some detail [1b]. Likely intermediates are mono- and di-nuclear silylene complexes, $\mathrm{M}=\mathrm{SiR} 2$ and $\mathrm{M}-\mathrm{SiR}_{2}-\mathrm{M}$, respectively, and complexed silanones. The remarkable stability of appropriately substituted silylenes has been demonstrated recently [12], and silanones are commonly postulated as intermediates [13].

\section{Acknowledgements}

The authors thank the Office of Naval Research for support of this work. A gift of dimethylchlorosilane from the Dow Corning Corporation is gratefully acknowledged, as is a loan of precious metals from Johnson Matthey, Inc. The GC-Mass Spectrometer was purchased with the aid of NSF Grant No. CHE77-11338.

\section{References}

1 (a) Part III: W.A. Gustavson, P.S. Epstein and M.D. Curtis, Organometallics, 1 (1982) 884; (b) Part II: M.D. Curtis and P.S. Epstein. Adv. Organometal. Chem., 19 (1981) 213: (c) Part I: M.D. Curtis and J. Greene, J. Am. Chem. Soc., 100 (1978) 6362.

2 The abbreviated notation for silicones used here is as follows: $E$ (end group) $=\mathrm{Me}_{3} \mathrm{SiO}_{1 / 2}, \mathrm{D}$ (difunctional) $=\mathrm{Me}_{2} \mathrm{SiO}_{2 / 2} ; \mathrm{T}$ (trifunctional) $=\mathrm{MeSiO}_{3 / 2}$. A primed letter indicates a substitution of hydrogen for methyl (i.e., $D^{\prime}=\mathrm{HMeSiO}_{2}$ ), and a superscript " $P$ "' indicates substitution of phenyl for methyl (e.g., E $E^{P}=\mathrm{PhMe}_{2} \mathrm{SiO}_{1 / 2}-$ ). For example: $\mathrm{Me}_{3} \mathrm{SiOSiMe}_{2} \mathrm{H}=\mathrm{EE}^{\prime} ; \mathrm{PhMe}_{2} \mathrm{SiOSiMe}_{2} \mathrm{OSiMe}_{2} \mathrm{H}=$ $E^{P} E^{\prime} ;\left(\mathrm{Me}_{3} \mathrm{SiO}_{3} \mathrm{SiH}=\mathrm{E}_{3} \mathrm{~T}^{\prime}\right.$, etc.

3 M.D. Curtis, J. Greene and W.M. Butler, J. Organometal. Chem., 164 (1979) 371.

4 S. Sokolow, J. Karnofsky. P. Gustafson. iNCOS Data System, Finnigan Application, Report No. 2. 1978, Finnegan Corporation, Sunnyvale, CA.

5 A detailed account of the identification of organosiloxanes by combined electron impact - (EIMS) and chemical ionization mass spectrometry (CIMS) will be given elsewhere: M.D. Curtis and P.S. Epstein, to be published.

6 J.E. Coutant and R.J. Robinson, in A.L. Smith (Ed.), Analysis of Silicones, Ch. 12, Wiley, New York, NY, 1974.

7 K. Vrieze, J.P. Collman and C.T. Sears, Inorg. Syn., 11 (1968) 101.

8 J.A. Osborne, F.H. Jardine, J.F. Young and G. Wilkinson, J. Chem. Soc. A, (1966) 1711.

9 The disiloxane, (HBzMeSi) 20 (Bz = benzyl), also gives a mixture of cis-and trans-metallacycles with $L_{2} P t^{0}=$ L.G. Bell, W.A. Gustavson and M.D. Curtis, submitted for publication.

10 D.R. Weyenberg, L.G. Malone and W.H. Atwell, Ann. N.Y. Acad. Sci., 159 (1969) 38.

11 W.A. Gustavson and M.D. Curtis, to be submitted.

12 (a) R. West, M.J. Fink and J. Michl, Science, 214 (1981) 1343; (b) S. Masamune, Y. Hanzawa, S. Murakami, T. Bally and J.F. Blount, J. Am. Chem. Soc., 104 (1982) 1150.

13 (a) C.M. Golino, R.D. Bush, D.N. Roark and L.H. Sommer, J. Organometal. Chem., 66 (1974) 29; (b) T.J. Barton and J.A. Kilgour, J. Am. Chem. Soc., 98 (1976) 7231 : (c) D. Sey ferth, T.F.O. Lim and D.P. Duncan, J. Am. Chem. Soc., 100 (1978) 1626. 